\title{
Resolving the Taxonomic Status of Chamelea gallina and C. striatula (Veneridae, Bivalvia): A Combined Molecular Cytogenetic and Phylogenetic Approach
}

\author{
Daniel García-Souto, Vesa Qarkaxhija, and Juan J. Pasantes \\ Departamento Bioquímica, Xenética e Inmunoloxía, Universidade de Vigo, Vigo, Spain \\ Correspondence should be addressed to Juan J. Pasantes; pasantes@uvigo.es
}

Received 31 January 2017; Revised 27 March 2017; Accepted 3 April 2017; Published 7 May 2017

Academic Editor: Daniele Corsaro

Copyright (C) 2017 Daniel García-Souto et al. This is an open access article distributed under the Creative Commons Attribution License, which permits unrestricted use, distribution, and reproduction in any medium, provided the original work is properly cited.

\begin{abstract}
The striped venus clams Chamelea gallina and C. striatula are commercially important bivalves inhabiting European and North African coastal waters. The taxonomic status of these taxa has been the subject of debate for decades. In order to elucidate this issue, we generated $5 \mathrm{~S}$ and $28 \mathrm{~S}$ ribosomal RNA and $\mathrm{H} 3$ histone gene probes and mapped them by fluorescent in situ hybridization to the chromosomes of morphologically identified striped venus clams, collected from four geographically distant Atlantic and Mediterranean populations. The nucleotide variation at the three DNA markers, that is, the nuclear internal transcribed spacer 2 (ITS2), the mitochondrial cytochrome c oxidase subunit I (COI), and the large ribosomal subunit rRNA (16S) fragments, was also studied and the resultant phylogenetic trees were evaluated. Striking differences in both the chromosome distribution of these genes and the clustering of the samples on the phylogenetic trees observed provide clear evidence that C. gallina and C. striatula are separated species.
\end{abstract}

\section{Introduction}

The striped venus clams Chamelea gallina (Linnaeus, 1758) and C. striatula (da Costa, 1778) (Bivalvia: Veneridae), the only extant species in the genus Chamelea Mörch, 1853, are filter feeding, sand burrowing bivalves inhabiting European and North African coastal waters. Even though these taxa are commercially exploited and economically valuable, for decades, their taxonomic status has been a matter of debate [1] that is still not completely settled. The confused status of these taxa is partially due to the use of variable shell and siphon characteristics to identify them. C. striatula is distinguished from C. gallina by possessing a more pointed and ridged shell and longer siphons [2] and by residing in the Atlantic [3]. On the basis of shell and siphon morphologies, C. striatula and $C$. gallina have been considered members of a single polymorphic species, two geographically isolated subspecies, or two different species. The lack of modern genetic studies applied to differentiate C. gallina and C. striatula also contributes to their uncertain status. The genetic distances estimated after studying seven polymorphic enzymes in samples obtained from striped venus clam mixed beds in the south of Portugal [2], supporting their status as separated species, are, as yet, the only genetic study applied to these taxa.

Although shell shape analyses [4] and geometric morphometric methods [3] have helped in accurately predicting the origin of some C. gallina samples and differentiating C. gallina from C. striatula, establishing taxonomic boundaries within bivalves has always been hindered by a lack of diagnostic morphological features [5]. This is due to an extensive parallelism of interspecific variability as a result of convergent evolution in response to the same environment alongside a degree of phenotypic divergence among populations of a single taxon developed on different substrates. Therefore, it is inaccurate to rely on morphology alone to delimit species boundaries and further criteria have to be analyzed [5].

In comparison with many other groups of organisms, cytogenetic analyses in clams of the family Veneridae are scarce. All species studied to date show a diploid chromosome number of $2 n=38[6,7]$ and their karyotypes are mostly 


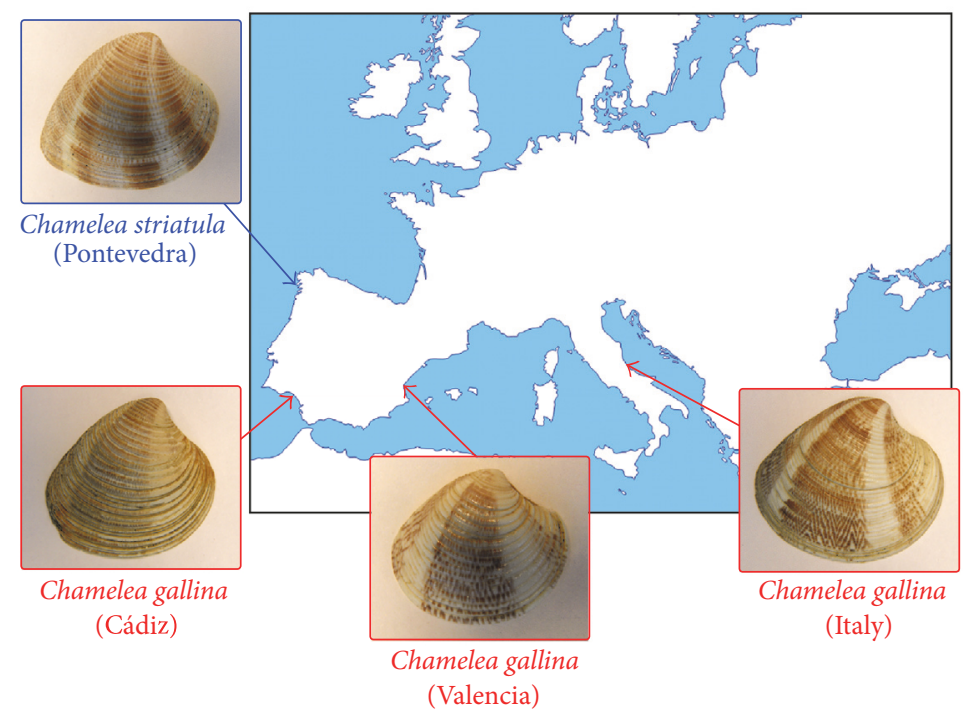

FIgURE 1: Collection localities and representative shells of the striped venus analyzed.

composed of chromosome pairs showing small differences in size and morphology, therefore making their accurate identification almost impossible [7]. As a resolution to this problem, along the last two decades, highly conserved repetitive DNA sequences have been used as probes in fluorescent in situ hybridization (FISH) experiments to identify chromosome pairs in bivalve species $[8,9]$, some of which were venus clams [7, 10-14]. Most commonly used DNA sequences for these types of studies are ribosomal RNA (rRNA) and histone genes as they are usually organized in tandems and clustered at one or more chromosomal positions. The employment of this approach in mussels of the Mytilus edulis species complex has allowed for differentiating M. edulis and M. galloprovincialis from $M$. trossulus by the chromosomal location of one of the $\mathrm{H} 3$ histone gene clusters and the number and location of the major rRNA gene (rDNA) clusters [15].

Chromosomal studies on striped venus clams are rarer than in other venerid clams. To the best of our knowledge, there is no published karyological information for $C$. striatula. For C. gallina, information is mostly limited to two reports describing chromosome number and karyotype composition and the location of major rDNA, $5 \mathrm{~S}$ rDNA, and $\mathrm{H} 3$ histone gene clusters $[7,16]$.

In regard to molecular phylogenetic analysis, many studies have utilized the mitochondrial cytochrome $c$ oxidase subunit I (COI) gene as the standard most accurate marker for delimitating and clarifying the taxonomic status of animal species, including venerid clams [17]. The mitochondrial 16S rRNA gen has also been successfully employed for species identification in clams $[17,18]$. These mitochondrial sequences are known to evolve faster than nuclear genes, making them ideal tools for detecting differences among closely related species and among populations within a species. In addition, the sequences of the internal transcribed spacer 2 (ITS2) of the 18S-5.8S-28S nuclear rDNA, and their corresponding secondary structures of the ITS 2 rRNAs, have also proved suitable for assessing phylogenetic and phylogeographic relationships among many animal taxa, some of them venerid clams [19].

In order to contribute to a better understanding of the evolutionary history and diversification within the genus Chamelea, we used an integrated approach based, on the one hand, on the comparison of the karyotypes constructed after mapping by FISH three tandemly repeated gene families (5S rDNA, 28S rDNA, and $\mathrm{H} 3$ histone genes) and, on the other hand, on the molecular phylogenies obtained from one nuclear (ITS2) and two mitochondrial (COI and 16S rRNA genes) sequences in striped venus clams collected from two Atlantic populations (Ría de Pontevedra, NW Spain; Gulf of Cádiz, S Spain) and two Mediterranean ones (Gulf of Valencia, E Spain; Adriatic Sea, E Italy). The genetic evidence obtained in this work confirms the consideration of C. gallina and C. striatula as separated species.

\section{Materials and Methods}

2.1. Sampling and Identification. Specimens of striped venus clams were collected (Figure 1) from different localities in Ría de Pontevedra (Atlantic coast, NW Spain) and identified as C. striatula, through their morphological attributes. Other striped venus clam samples, identified as C. gallina, were collected from natural beds in Valencia (Gulf of Valencia, Mediterranean coast, E Spain) and from local market places in coastal towns of the Gulf of Cádiz (Atlantic coast, S Spain) and the Adriatic Sea (Mediterranean coast, E Italy). The nomenclature utilized for these taxa follows the World Register of Marine Species (WoRMS) database (http://www.marinespecies.org/). In all cases, striped venus clams were transported alive to the lab, maintained in tanks of $5 \mathrm{~L}$ filtered seawater at $18 \pm 1^{\circ} \mathrm{C}$, and fed on microalgae to promote somatic growth. 
2.2. Chromosome Preparation. Chromosome spreads were obtained as previously published [20,21]. Following an in vivo colchicine $(0.005 \%, 10 \mathrm{~h})$ treatment, striped venus clams were dissected and gills and gonads were immersed in diluted sea water $(50 \%, 20 \mathrm{~min} ; 25 \%, 20 \mathrm{~min})$. After fixation in ethanol/acetic acid ( $3: 1 ; 3$ times $20 \mathrm{~min}$ ), pieces of tissue were disaggregated in $60 \%$ acetic acid and the cell suspensions spread onto warm microscope slides [22, 23].

\subsection{DNA Extraction and PCR Amplification. DNA was} extracted from adductor muscles using a phenol-chloroformisoamyl alcohol method [24]. A fragment of the mitochondrial COI gene was amplified by PCR employing the standard barcoding primers LCO1490 and HCO2198 [25]. A fragment of the mitochondrial 16S rRNA gene was amplified by means of primers $16 \mathrm{~L} 29$ [26] and $16 \mathrm{SBr}$ [27]. The complete ITS2 of the major rDNA was amplified using primers ITS 3 and ITS4 [28]. On FISH mapping purposes, universal primers LRIOR and LR12 retrieved from Vilgalys lab website [29] were used to amplify a fragment of the $28 \mathrm{~S} \mathrm{rDNA}$. Amplifications of the entire 5S rDNA repeat and the $\mathrm{H} 3$ histone genes used primers described by Pérez-García et al. [22, 23] and Giribet and Distel [30], respectively.

DNA sequences were amplified in a GeneAmp PCR system 9700 (Applied Biosystems) in $50 \mu \mathrm{L}$ solutions containing $125 \mathrm{ng}$ of genomic DNA, $50 \mu \mathrm{M}$ each dNTP, $50 \mu \mathrm{M}$ each primer, 1xPCR buffer, $15 \mu \mathrm{M} \mathrm{MgCl}_{2}$, and $5 \mathrm{U}$ of JumpStart ${ }^{\mathrm{TM}}$ Taq DNA Polymerase (Sigma). Amplifications included an initial denaturation step at $95^{\circ} \mathrm{C}(2 \mathrm{~min}), 35$ amplification cycles (Supplementary Table 1, in Supplementary Material available online at https://doi.org/10.1155/2017/ 7638790), and a final extension at $72^{\circ} \mathrm{C}(5 \mathrm{~min})$. PCR products were examined by electrophoresis on $2 \%$ agarose gels.

2.4. DNA Sequencing and Phylogenetic Analysis. Amplified mitochondrial 16S rRNA and COI genes and nuclear ITS2 rDNA sequences were purified (FavorPrep ${ }^{\mathrm{TM}}$ GEL/PCR Purification Kit, Favorgen) and sequenced (CACTI, University of Vigo) in both directions in an ABI PRISM 3730 Genetic Analyzer (Applied Biosystems) using a BigDye Terminator v. 3.1 Cycle Sequencing Kit (Applied Biosystems). The sequences were edited with BioEdit v. 7.1.11 [31] and aligned with Muscle set to default parameters using MEGA7 [32]. Sequence similarity searches were performed using the Basic Local Alignment Search Tool (BLAST) algorithm, available at the National Center for Biotechnology Information (NCBI) (http://www.ncbi.nlm.nih.gov/blast). The MegaBLAST algorithm set to default parameters was employed against both NCBI nucleotide collection and NCBI nucleotide collection and Barcode of Life Data System (BOLD) databases. After removing primers, maximum-likelihood (ML) phylogenetic analyses were performed. The best-fit nucleotide substitution models were selected (COI gene: JC + G; 16S rRNA gene: HKY+G; ITS2: T92) by the AIC criterion employing JModelTest $2[33,34]$. ML reliability was assessed with 500 bootstrap replicates. All phylogenetic analyses were performed on MEGA7 [32]. Nucleotide diversity (pi) and uncorrected pairwise $p$-distances were estimated using DnaSP v. 5 [35] and MEGA7 [32], respectively.
2.5. Fluorescence In Situ Hybridization (FISH). Single, double, and sequential FISH experiments using $5 \mathrm{~S}$ and $28 \mathrm{~S}$ rDNA and $\mathrm{H} 3$ histone gene probes were performed on metaphase chromosome spreads obtained from striped venus clams collected in all four regions. Biotin and digoxigenin labeled probes were generated either directly by PCR or by nick translation [36]. Chromosome slides were digested with RNase and pepsin before denaturation $\left(70^{\circ} \mathrm{C}, 2 \mathrm{~min}\right)$ and hybridized overnight at $37^{\circ} \mathrm{C}$. Biotin was detected with fluorescein isothiocyanate (FITC) conjugated avidin and biotinylated anti-avidin (Vector) whereas digoxigenin was detected with anti-digoxigenin antibodies conjugated with tetramethylrhodamine isothiocyanate (TRITC) (Sigma). Chromosome slides were counterstained with $4^{\prime}$-6-diamidino-2phenylindole (DAPI, $0.14 \mu \mathrm{g} / \mathrm{mL}$ in $2 x S S C$ ) and mounted with antifade (Vectashield, Vector).

Chromosome preparations were examined with a Nikon Eclipse-800 microscope equipped with an epifluorescence system [36]. Separated images for each fluorochrome were recorded and pseudocolored using a DS-QilMc CCD camera (Nikon) controlled by the NIS-Elements software (Nikon). Merging of the images was performed with Adobe Photoshop.

\section{Results}

3.1. Karyotypes and Chromosomal Mapping of rDNA and H3 Histone Gene Clusters. All striped venus clams analyzed showed mitotic metaphase plates presenting 38 chromosomes (Figure 2). The karyotypes constructed for the four striped venus clam populations (Figure 2) were roughly similar for 18 of the chromosome pairs ( 7 metacentric, 6 meta/submetacentric, 2 submetacentric, and 3 subtelocentric) but the remaining one (number 19 for comparative purposes) showed morphological differences. This chromosome pair was subtelocentric in both C. striatula and the Italian C. gallina and metacentric in the two Spanish C. gallina populations.

FISH mapping of 5S rDNA probes showed intercalary signals located in two metacentric chromosome pairs $(5 \mathrm{p}$ and $9 q$ ) in all striped venus clams regardless of origin and whether they were morphologically identified as C. gallina or C. striatula (Figure 2). In contrast, the number and the distribution of the signals corresponding to both $28 \mathrm{~S}$ rDNA and $\mathrm{H} 3$ histone gene probes evinced some differences. All striped venus clam specimens presented at minimum a single $28 \mathrm{~S}$ rDNA signal situated in the neighborhood of the centromere on chromosome pair 19; whereas this is the only signal in C. gallina, an additional signal subterminal to $8 \mathrm{q}$ appeared in C. striatula (Figure 2). Likewise, although H3 histone gene probes were subterminal to $15 \mathrm{q}$ and $17 \mathrm{q}$ in all striped venus clams, further signals were present in both the Italian C. gallina population $(6 \mathrm{q})$ and in C. striatula (6q and 5q).

Double-color FISH mapping using $5 \mathrm{~S}$ rDNA and $\mathrm{H} 3$ histone gene probes also confirmed the presence of signals for both probes on C. striatula chromosome pair 5. This chromosome pair only bears $5 \mathrm{~S}$ rDNA clusters in C. gallina. 

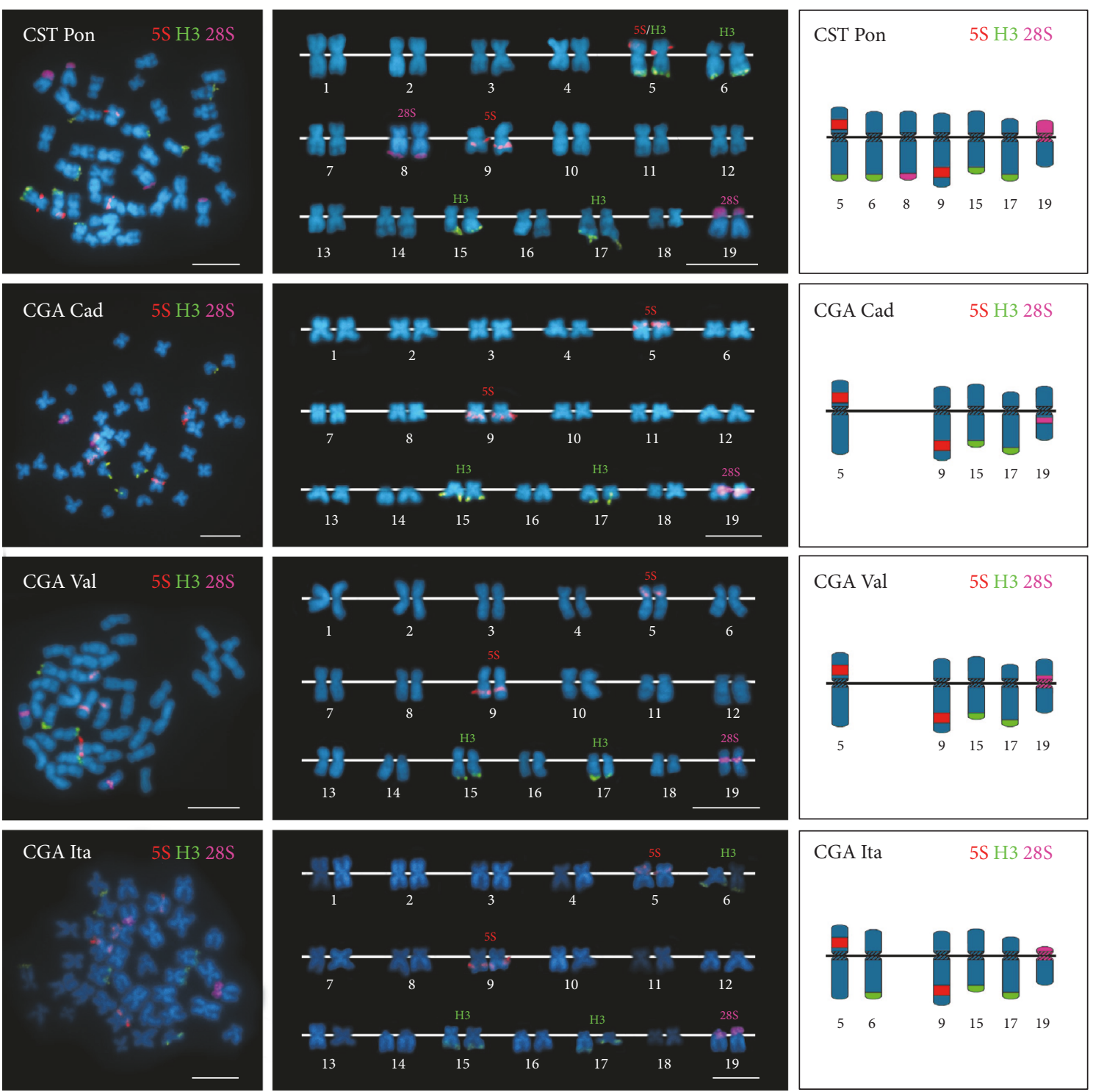

FIGURE 2: FISH mapping of 5S rRNA (5S, red), $28 \mathrm{~S}$ rRNA (28S, magenta), and H3 histone gene (H3, green) probes to mitotic metaphase chromosomes of striped venus clams Chamelea striatula from Pontevedra (CST Pon) and Chamelea gallina from Cádiz (CGA Cad), Valencia (CGA Val), and Italy (CGA Ita) counterstained with DAPI. The corresponding karyotypes and schematic representations of the signal bearing chromosomes are also included. Note that all chromosome pairs present a single signal with the exception of CST Pon chromosome pair 5 that bears both $5 \mathrm{~S}$ rDNA and $\mathrm{H} 3$ histone gene clusters. Scale bars, $5 \mu \mathrm{m}$.

In all four populations, variation in signal patterning was low, and aberrance was reduced to a pericentric inversion or an additional $28 \mathrm{~S}$ rDNA signal in four of the 55 C. striatula specimens and one additional 28S rDNA signal in two of the 28 specimens of the Italian C. gallina.

3.2. DNA Sequence Variation and Genetic Divergence. A fragment of $629 \mathrm{bp}$, excluding primers, of the mitochondrial COI gene was sequenced for 20 striped venus clams, five per population (GenBank acc. numbers KY547747 to KY547766). The sequences showed 89 polymorphic sites and 78 differentially fixed mutations. The nucleotide diversity was 0.0556 (Table 1) and the genetic distance between taxa was $13.20 \%$ (Table 2).
The comparison of these sequences with those stored in GenBank showed that our C. striatula sequences coincided in a 99\% with those from North Sea C. gallina samples [37]. The C. gallina COI sequences displayed a high level of homology (98\%) with samples from the Adriatic Sea (GenBank acc. numbers DQ458474 and KR078004) and a market place in the Canary Islands (GenBank acc. number DQ184835). Pairwise genetic distances between populations inferred from the mitochondrial COI gene sequences (Table 2) showed that C. striatula is clearly distinct from the three C. gallina populations. Likewise, the ML tree recovered by MEGA on these sequences (using Dosinia exoleta as outgroup) revealed two well supported clades, one formed by the specimens 


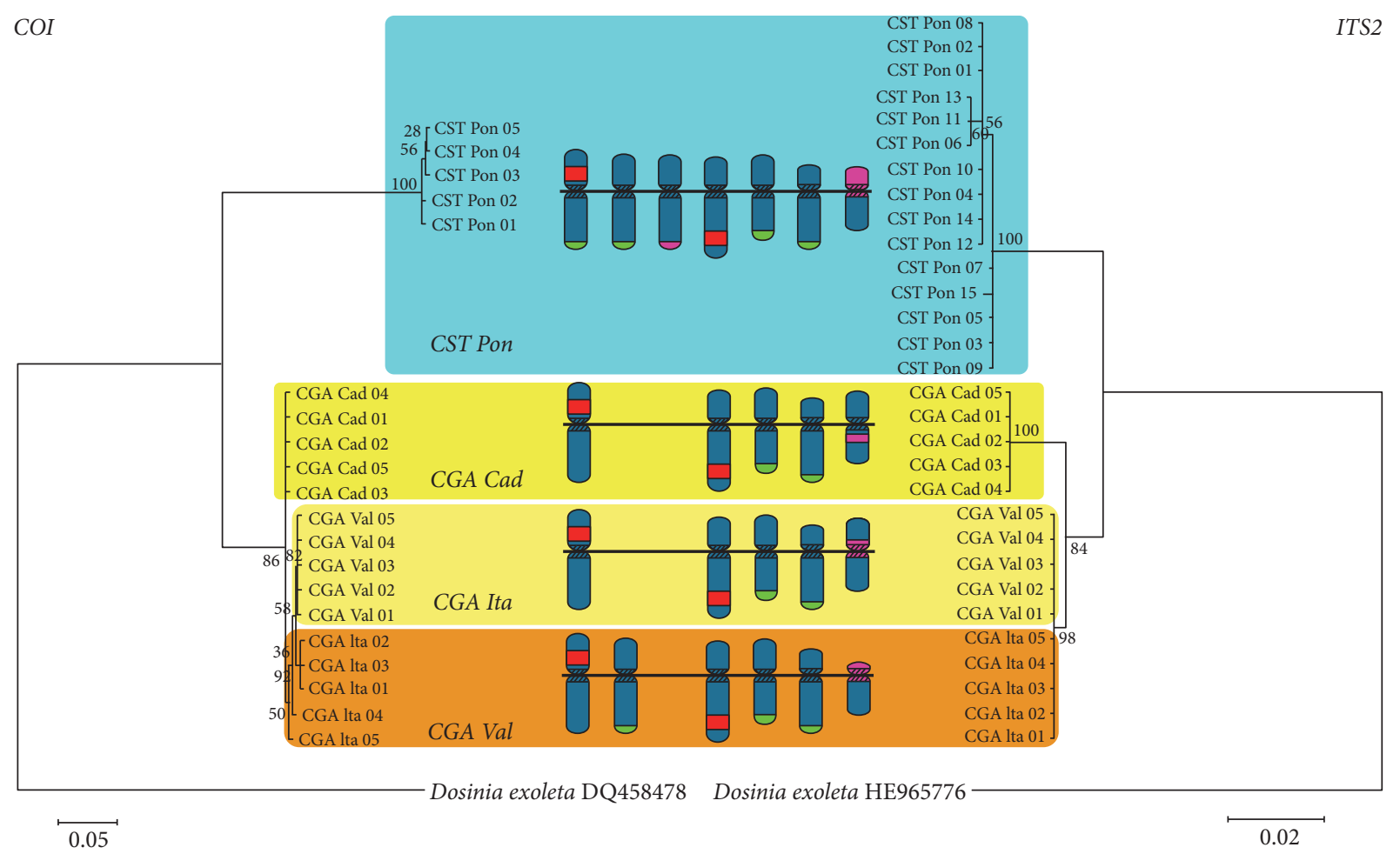

FIGURE 3: Maximum-likelihood trees based on mitochondrial COI gene and nuclear ITS2 sequences of striped venus clams using Dosinia exoleta as outgroup together with a schematic representation of the main chromosomal differences. Numbers in internal nodes indicate maximum-likelihood bootstrap support values (500 replicates).

TABLE 1: Nucleotide diversity (pi) of COI gene, $16 \mathrm{~S}$ rDNA, and ITS2 sequences in Chamelea gallina and Chamelea striatula.

\begin{tabular}{lcccccc}
\hline & \multicolumn{2}{c}{ COI gene } & \multicolumn{2}{c}{ 16S rDNA } & \multicolumn{2}{c}{ ITS2 } \\
& $n$ & pi & $n$ & pi & $n$ & pi \\
\hline $\begin{array}{l}\text { Chamelea striatula } \\
\quad \text { CST Pon }\end{array}$ & 5 & 0.0022 & 5 & 0.0000 & 15 & 0.0021 \\
$\begin{array}{l}\text { Chamelea gallina } \\
\text { CST Cad }\end{array}$ & 5 & 0.0000 & 5 & 0.0000 & 5 & 0.0000 \\
CST Val & 5 & 0.0000 & 5 & 0.0000 & 5 & 0.0000 \\
CST Ita & 5 & 0.0057 & 5 & 0.0035 & 5 & 0.0000 \\
All CST & 15 & 0.0060 & 15 & 0.0030 & 15 & 0.0063 \\
All Chamelea & 20 & 0.0556 & 20 & 0.0443 & 30 & 0.0202 \\
\hline
\end{tabular}

morphologically identified as C. striatula and the other by the specimens identified as C. gallina with bootstrap values of $100 \%$ and $86 \%$, respectively (Figure 3 ).

The sequenced 16S rRNA gene fragments were $468 \mathrm{bp}$ long in the specimens collected from Pontevedra (C. striatula) and 466 bp long in all C. gallina specimens (GenBank acc. numbers KY547767 to KY547786). The difference in length was due to six between-taxa gaps: two single nucleotide and one dinucleotide insertions in C. striatula and two single nucleotide insertions in C. gallina. There were 51 polymorphic sites, 48 of them taxa specific, providing a genetic distance between taxa of $11.44 \%$. The nucleotide diversity was 0.0443 (Table 1). These 16S rRNA gene sequences were also
TABLE 2: Pairwise $p$-distances between striped venus clam populations using mitochondrial COI and 16S rRNA genes and nuclear ITS2 sequences. Interspecific distances in bold.

\begin{tabular}{lcccc}
\hline \multicolumn{2}{c}{ Populations } & COI gene & 16S rDNA & ITS2 \\
\hline CST Pon & CGA Cad & $\mathbf{0 . 1 3 0 4}$ & $\mathbf{0 . 1 1 2 1}$ & $\mathbf{0 . 0 3 9 6}$ \\
CST Pon & CGA Val & $\mathbf{0 . 1 3 2 0}$ & $\mathbf{0 . 1 1 6 4}$ & $\mathbf{0 . 0 3 3 0}$ \\
CST Pon & CGA Ita & $\mathbf{0 . 1 3 3 5}$ & $\mathbf{0 . 1 1 4 7}$ & $\mathbf{0 . 0 3 3 0}$ \\
CGA Cad & CGA Val & 0.0095 & 0.0043 & 0.0132 \\
CGA Cad & CGA Ita & 0.0086 & 0.0047 & 0.0132 \\
CGA Val & CGA Ita & 0.0048 & 0.0022 & 0.0000 \\
CST & CGA & $\mathbf{0 . 1 3 2 0}$ & $\mathbf{0 . 1 1 4 4}$ & $\mathbf{0 . 0 3 5 2}$ \\
\hline
\end{tabular}

compared with the six sequences stored in GenBank. The $C$. striatula sequences were identical to sequences from England (GenBank acc. numbers DQ280041 and KX713203) whereas those from C. gallina matched the sequences of specimens from Turkey (GenBank acc. number AM085110), Adriatic Sea (GenBank acc. number AJ548762), NW Spain (GenBank acc. number JF808193), and a market in the Canary Islands (GenBank acc. number DQ184735). Again, both the pairwise distances (Table 2) and the ML tree recovered (not shown) differentiated specimens belonging to the two taxa (bootstrap values of $100 \%$ and $72 \%$ ).

The amplified ITS2 fragments (GenBank acc. numbers KY508254 to KY508283) were the most inconsistent in 
length. While all specimens of the Mediterranean populations of C. gallina displayed $498 \mathrm{bp}$ long fragments, in the Atlantic specimens, the ITS2 was 496 bp long; these differences in length were a result of a dinucleotide insertion (or deletion) and six nucleotide substitutions. In contrast, five specimens of the C. striatula population displayed $498 \mathrm{bp}$ long ITS2 fragments whereas the remaining 10 exhibited 495 bp long fragments, due to a trinucleotide insertion and two point mutations. Sequence analysis of the ITS2 for all striped venus clams revealed 34 polymorphic sites and, excluding gaps, 13 differentially fixed mutations between the two taxa. The nucleotide diversity was 0.0202 (Table 1) and the genetic distance between taxa was 3.52\% (Table 2). While the Atlantic C. gallina sequences obtained in this work were identical to those from Tyrrhenian Sea specimens (GenBank acc. numbers HE965773 and HE965774), the two Mediterranean populations ITS2 sequences coincided with those from Adriatic Sea samples (GenBank acc. numbers HE965771 and HE965772). No C. striatula ITS2 sequences were found in GenBank. The pairwise genetic distances between populations inferred from nuclear ITS2 sequences (Table 2) also depicted that C. striatula is clearly separated from the three C. gallina populations and the ML tree also recovered two clades with bootstrap values of $100 \%$ and $84 \%$ (Figure 3).

In addition, the predicted folding shapes of the C. gallina ITS2 rRNAs (Supplementary Figure 1) were identical to those previously published for the same species [19]; those for $C$. striatula were concordant with the structure proposed for Veneridae [19]. Most point mutations detected (17 of a total of 20), including those differentiating taxa and populations, were clustered on the DIV-DVI stems, the less conserved area in terms of primary sequence [19].

\section{Discussion and Conclusion}

The taxonomic status of the striped venus clams C. gallina and C. striatula has been a matter of debate for decades [1]. Although the World Register of Marine Species have recognized them as separated species since $2004[38,39]$, the distribution ranges of these taxa displayed in WoRMs, from the North Atlantic to the Eastern Mediterranean, still overlap in almost their entirety. Moreover, even as recently as last year, COI gene sequences obtained from North Sea samples, therefore C. striatula, were stored in GenBank under the specific name C. gallina [37]. In order to resolve this issue, we applied a molecular cytogenetic approach, from the perspective of chromosomal distribution of three gene families [7, 1214], alongside comparing the sequences of mitochondrial and nuclear DNA markers, that are increasingly being utilized in phylogenetic studies $[5,17-19,40,41]$, to further insight and strengthen the evidence.

The diploid chromosome number of $2 n=38$ obtained in this work is in accordance with those previously described for C. gallina $[7,16]$ and all other Veneridae studied to date [6-8, 12-14]. The karyotype compositions obtained were also fundamentally coincidental with that proposed for C. gallina [16].
Discordant with their conserved chromosome numbers, the species of Veneridae present clear differences in the number and distribution of rDNA and histone gene clusters on their chromosomes [7, 12-14]. These differences are also present in closely related, congeneric species and are usually accompanied with an almost complete absence of intraspecific variability [7, 12-14].

Our results demonstrated that this is also the case for the two striped venus clam taxa studied. The consistency in the $5 \mathrm{~S}$ rDNA signal pattern and the mapping differences for both 28S rDNA and H3 histone gene signals found between $C$. gallina and C. striatula are of a similar magnitude to those reported for Venus casina/V. verrucosa and Dosinia exoleta/D. lupinus [7]. Conversely, although we found some mapping differences among C. gallina populations and among $C$. striatula specimens, these differences were comparatively narrower than those between taxa and similar to those found in other bivalve species $[23,36]$, thusly constituting the standard intraspecific variation.

The sequence data obtained also indicated that these two taxa are separated species. All individual ML trees recovered by MEGA on the COI gene, 16S rRNA gene, and ITS2 sequences (using Dosinia exoleta as outgroup) revealed two clearly separated, well supported clades, one formed by the specimens morphologically identified as C. striatula and the other by the specimens identified as C. gallina. Furthermore, the genetic distances between the C. striatula population and any of the $C$. gallina populations were indubitably higher than those between any two C. gallina populations for both mitochondrial and nuclear sequences. The magnitudes of these genetic distances were fully concordant with those previously reported for congeneric species of Veneridae, both for the mitochondrial COI gene [5] and the nuclear ITS2 [19] sequences analyzed.

In conclusion, the results obtained in this study after employing two mitochondrial and one nuclear DNA markers together with three chromosomal markers in four geographically distant populations of striped venus clams clearly demonstrate that C. gallina and C. striatula are well differentiated species.

\section{Conflicts of Interest}

The authors declare that there are no conflicts of interest regarding the publication of this article.

\section{Acknowledgments}

The authors wish to thank M. Lastra and M. Rodríguez for kindly providing some of the striped venus clams. This work was partly funded by grants from Xunta de Galicia and Fondos FEDER: "Unha maneira de facer Europa" (08MMA023310PR; Axudas do programa de consolidación e estruturación de unidades de investigacións competitivas do SUG: ED431C 2016-037). D. García-Souto was partially supported by a FPU fellowship from Ministerio de Educación (Spain). 


\section{References}

[1] P. Bouchet, "The magnitude of marine diversity," in The Exploration of Marine Diversity: Scientific and Technological Challenges, C. Duarte, Ed., pp. 31-64, Fundación BBVA, Bilbao, Spain, 2006.

[2] T. Backeljau and S. Gofas, "Genetic variation, systematics and distribution of the venerid clam Chamelea gaeeina," Journal of the Marine Biological Association of the United Kingdom, vol. 74, no. 1, pp. 211-223, 1994.

[3] M. M. Rufino, M. B. Gaspar, A. M. Pereira, and P. Vasconcelos, "Use of shape to distinguish Chamelea gallina and Chamelea striatula (Bivalvia: Veneridae): linear and geometric morphometric methods," Journal of Morphology, vol. 267, no. 12, pp. 1433-1440, 2006.

[4] M. Palmer, G. X. Pons, and M. Linde, "Discriminating between geographical groups of a Mediterranean commercial clam (Chamelea gallina (L.): Veneridae) by shape analysis," Fisheries Research, vol. 67, no. 1, pp. 93-98, 2004.

[5] J. Chen, Q. Li, L. Kong, and H. Yu, "How DNA barcodes complement taxonomy and explore species diversity: the case study of a poorly understood marine fauna," PLoS ONE, vol. 6, no. 6, Article ID e21326, 2011.

[6] C. Thiriot-Quiévreux, "Advances in cytogenetics of aquatic organisms," in Genetics and Evolution of Aquatic Organisms, A. R. Beaumont, Ed., pp. 369-388, Chapman and Hall, London, UK, 1994.

[7] D. García-Souto, C. Pérez-García, P. Morán, and J. J. Pasantes, "Divergent evolutionary behavior of $\mathrm{H} 3$ histone gene and rDNA clusters in venerid clams," Molecular Cytogenetics, vol. 8, no. 1, article 40, 2015.

[8] A. Leitão and R. Chaves, "Banding for chromosomal identification in bivalves: a 20-year history," Dynamic Biochemistry, Process Biotechnology and Molecular Biology, vol. 2, no. 1, pp. 44-49, 2008.

[9] D. García-Souto, C. Pérez-García, J. Kendall, and J. J. Pasantes, "Molecular cytogenetics in trough shells (Mactridae, Bivalvia): divergent GC-rich heterochromatin content," Genes, vol. 7, no. 8, article 47, 2016.

[10] N. S. Hurtado and J. J. Pasantes, "Surface spreading of synaptonemal complexes in the clam Dosinia exoleta (Mollusca, Bivalvia)," Chromosome Research, vol. 13, no. 6, pp. 575-580, 2005.

[11] Y. Wang and X. Guo, "Chromosomal mapping of major ribosomal rRNA genes in the hard clam (Mercenaria mercenaria) using fluorescence in situ hybridization," Marine Biology, vol. 150, no. 6, pp. 1183-1189, 2007.

[12] J. Carrilho, C. Pérez-García, A. Leitão, I. Malheiro, and J. J. Pasantes, "Cytogenetic characterization and mapping of rDNAs, core histone genes and telomeric sequences in Venerupis aurea and Tapes rhomboides (Bivalvia: Veneridae)," Genetica, vol. 139, no. 6, pp. 823-831, 2011.

[13] N. S. Hurtado, C. Pérez-García, P. Morán, and J. J. Pasantes, "Genetic and cytological evidence of hybridization between native Ruditapes decussatus and introduced Ruditapes philippinarum (Mollusca, Bivalvia, Veneridae) in NW Spain," Aquaculture, vol. 311, no. 1-4, pp. 123-128, 2011.

[14] C. Pérez-García, N. S. Hurtado, P. Morán, and J. J. Pasantes, "Evolutionary dynamics of rDNA clusters in chromosomes of five clam species belonging to the family Veneridae (Mollusca, Bivalvia)," BioMed Research International, vol. 2014, Article ID 754012, 9 pages, 2014.
[15] C. Pérez-García, P. Morán, and J. J. Pasantes, "Karyotypic diversification in Mytilus mussels (Bivalvia: Mytilidae) inferred from chromosomal mapping of rRNA and histone gene clusters," BMC Genetics, vol. 15, article 84, 2014.

[16] M. G. Corni and M. Trentini, "A chromosomic study of Chamelea gallina (L.) (Bivalvia, Venerihdae)," Bolletino di zoologia, vol. 53, no. 1, pp. 23-24, 1986.

[17] J. Chen, Q. Li, L. Kong, and X. Zheng, "Molecular phylogeny of venus clams (Mollusca, Bivalvia, Veneridae) with emphasis on the systematic position of taxa along the coast of mainland China," Zoologica Scripta, vol. 40, no. 3, pp. 260-271, 2011.

[18] A. Canapa, S. Schiaparelli, I. Marota, and M. Barucca, "Molecular data from the 16S rRNA gene for the phylogeny of Veneridae (Mollusca: Bivalvia)," Marine Biology, vol. 142, no. 6, pp. 11251130, 2003.

[19] D. Salvi and P. Mariottini, "Molecular phylogenetics in 2D: ITS2 rRNA evolution and sequence-structure barcode from Veneridae to Bivalvia," Molecular Phylogenetics and Evolution, vol. 65, no. 2, pp. 792-798, 2012.

[20] J. Pasantes, M. J. Martinez-expósito, A. Martinez-lage, and J. Méndez, "Chromosomes of galician mussels," Journal of Molluscan Studies, vol. 56, no. 1, pp. 123-126, 1990.

[21] M. J. Martínez-Expósito, J. J. Pasantes, and J. Méndez, "Proliferation kinetics of mussel (Mytilus galloprovincialis) gill cells," Marine Biology, vol. 120, no. 1, pp. 41-45, 1994.

[22] C. Pérez-García, J. M. Cambeiro, P. Morán, and J. J. Pasantes, "Chromosomal mapping of rDNAs, core histone genes and telomeric sequences in Perumytilus purpuratus (Bivalvia: Mytilidae)," Journal of Experimental Marine Biology and Ecology, vol. 395, no. 1-2, pp. 199-205, 2010.

[23] C. Pérez-García, J. Guerra-Varela, P. Morán, and J. J. Pasantes, "Chromosomal mapping of rRNA genes, core histone genes and telomeric sequences in Brachidontes puniceus and Brachidontes rodriguezi (Bivalvia, Mytilidae)," BMC Genetics, vol. 11, article 109,2010

[24] B. Winnepenninckx, T. Backeljau, and R. de Wachter, "Extraction of high molecular weight DNA from molluscs," Trends in Genetics, vol. 9, no. 12, p. 407, 1993.

[25] O. Folmer, M. Black, W. Hoeh, R. Lutz, and R. Vrijenhoek, "DNA primers for amplification of mitochondrial cytochrome c oxidase subunit I from diverse metazoan invertebrates," Molecular Marine Biology and Biotechnology, vol. 3, no. 5, pp. 294-299, 1994.

[26] C. D. Schubart, J. E. Conde, C. Carmona-Suárez, R. Robles, and D. L. Felder, "Lack of divergence between $16 \mathrm{~S}$ mtDNA sequences of the swimming crabs Callinectes bocourti and C. maracaiboensis (Brachyura: Portunidae) from Venezuela," Fishery Bulletin, vol. 99, no. 3, pp. 475-481, 2001.

[27] S. R. Palumbi, "Nucleic acids II. The polymerase chain reaction," in Molecular Systematics, D. M. Hillis, C. Moritz, and B. K. Mable, Eds., pp. 205-247, Sinauer Associates, Sunderland, Mass, USA, 2nd edition, 1996.

[28] T. J. White, T. Burms, S. Lee, and J. W. Taylor, "Amplification and direct sequences of fungal ribosomal RNA genes for phylogenetics," in PCR Protocols: A Guide to Methods and Applications, M. A. Inmus, D. H. Guelfand, J. J. Sminsky, and T. J. White, Eds., pp. 315-322, Academic Press, New York, NY, USA, 1990.

[29] R. Vilgalys, Duke University, Durham, NC, USA, http://www .biology.duke.edu/fungi/mycolab/primers.htm.

[30] G. Giribet and D. Distel, "Bivalve phylogeny and molecular data," in Systematics and Phylogeography of Molluscks, 
C. Lydeard and D. R. Lindberg, Eds., pp. 45-90, Smithsonian Books, Washington, Wash, USA, 2003.

[31] T. A. Hall, "BioEdit: a user-friendly biological sequence alignment editor and analysis program for Windows 95/98/NT," Nucleic Acids Symposium Series, vol. 41, pp. 95-98, 1999.

[32] S. Kumar, G. Stecher, and K. Tamura, "MEGA7: molecular evolutionary genetics analysis version 7.0 for bigger datasets," Molecular Biology and Evolution, vol. 33, no. 7, pp. 1870-1874, 2016.

[33] D. Darriba, G. L. Taboada, R. Doallo, and D. Posada, "JModelTest 2: more models, new heuristics and parallel computing," Nature Methods, vol. 9, no. 8, article 772, p. 772, 2012.

[34] S. Guindon and O. Gascuel, "A simple, fast, and accurate algorithm to estimate large phylogenies by maximum likelihood," Systematic Biology, vol. 52, no. 5, pp. 696-704, 2003.

[35] P. Librado and J. Rozas, "DnaSP v5: a software for comprehensive analysis of DNA polymorphism data," Bioinformatics, vol. 25, pp. 1451-1452, 2009.

[36] C. Pérez-García, P. Morán, and J. J. Pasantes, “Cytogenetic characterization of the invasive mussel species Xenostrobus securis Lmk. (Bivalvia: Mytilidae)," Genome, vol. 54, no. 9, pp. 771-778, 2011.

[37] A. Barco, M. J. Raupach, S. Laakmann, H. Neumann, and T. Knebelsberger, "Identification of North Sea molluscs with DNA barcoding," Molecular Ecology Resources, vol. 16, no. 1, pp. 288297, 2016.

[38] S. Gofas, "Chamelea gallina (Linnaeus, 1758)," in MolluscaBase (2016), 2004, World Register of Marine Species http://www .marinespecies.org/aphia.php? $\mathrm{p}=$ taxdetails\&amp;id=141907.

[39] S. Gofas, "Chamelea striatula (da Costa, 1778)," in MolluscaBase (2016), 2004, World Register of Marine Species http://www .marinespecies.org/aphia.php?p=taxdetails\&amp;id=141908.

[40] I. Kappner and R. Bieler, "Phylogeny of venus clams (Bivalvia: Venerinae) as inferred from nuclear and mitochondrial gene sequences," Molecular Phylogenetics and Evolution, vol. 40, no. 2, pp. 317-331, 2006.

[41] P. M. Mikkelsen, R. Bieler, I. Kappner, and T. A. Rawlings, "Phylogeny of Veneroidea (Mollusca: Bivalvia) based on morphology and molecules," Zoological Journal of the Linnean Society, vol. 148, no. 3, pp. 439-521, 2006. 

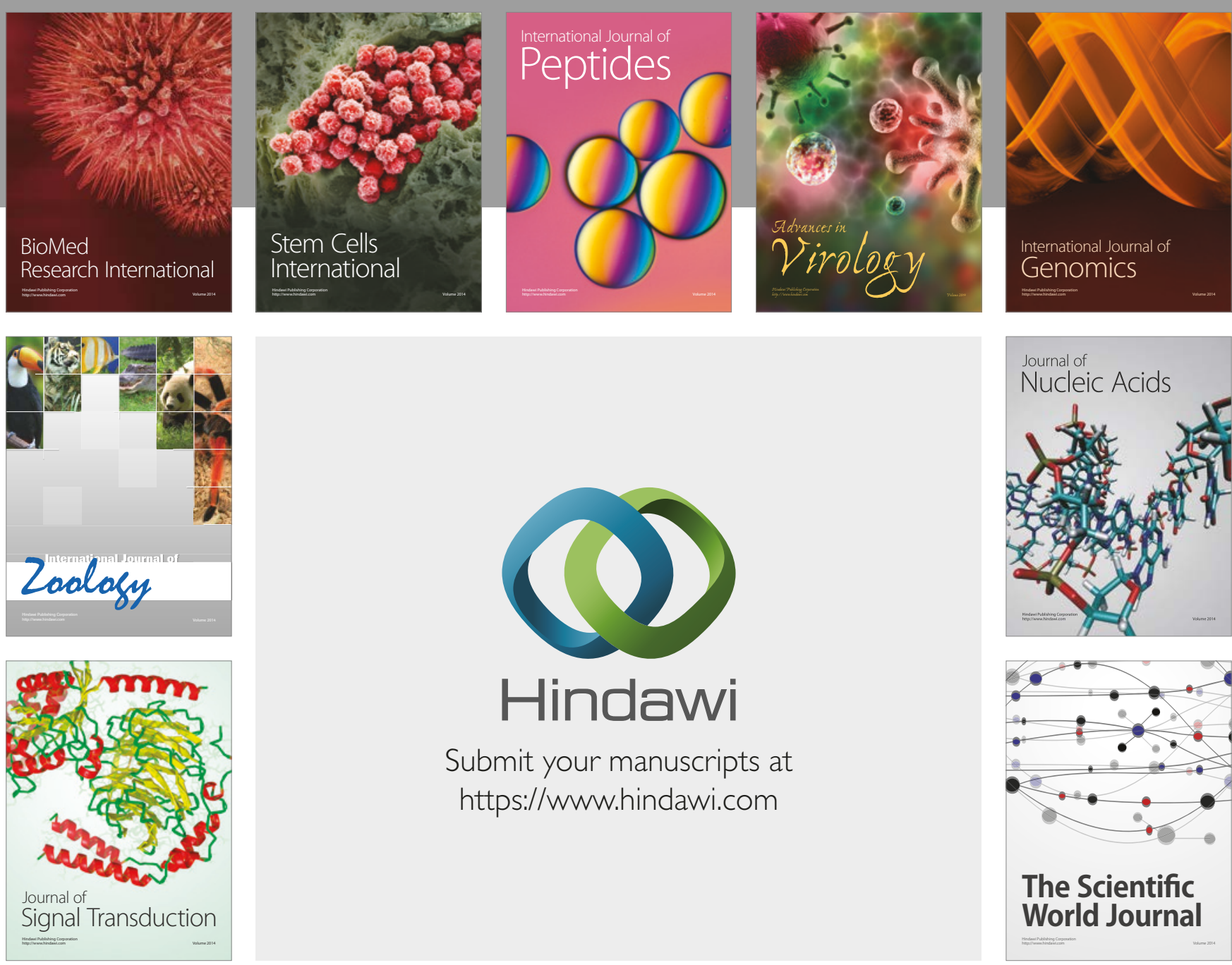

Submit your manuscripts at

https://www.hindawi.com
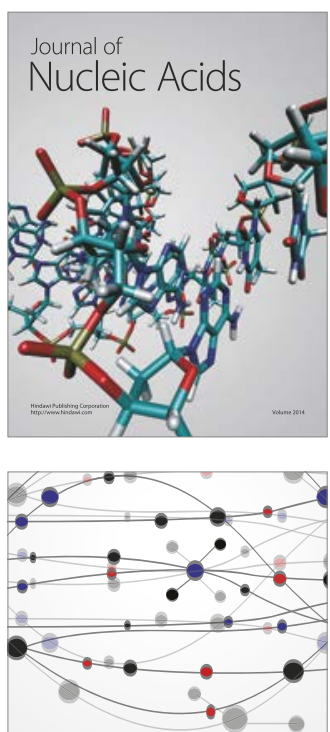

The Scientific World Journal

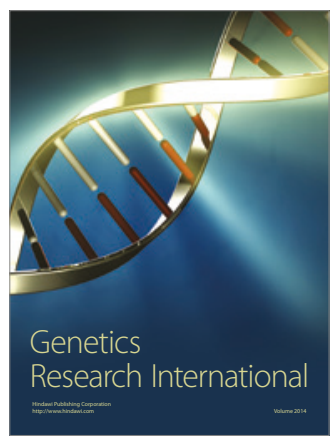

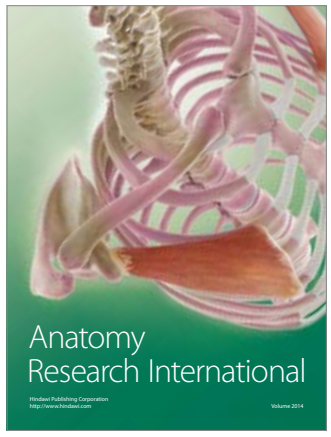

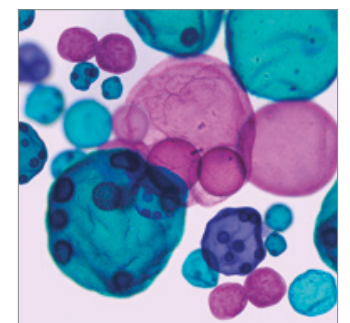

International Journal of Microbiology
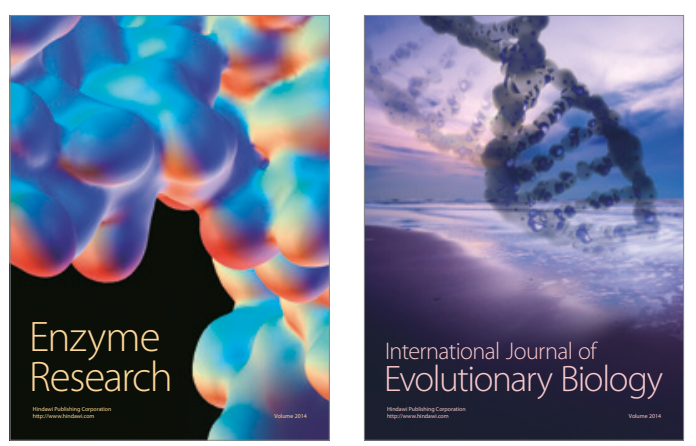
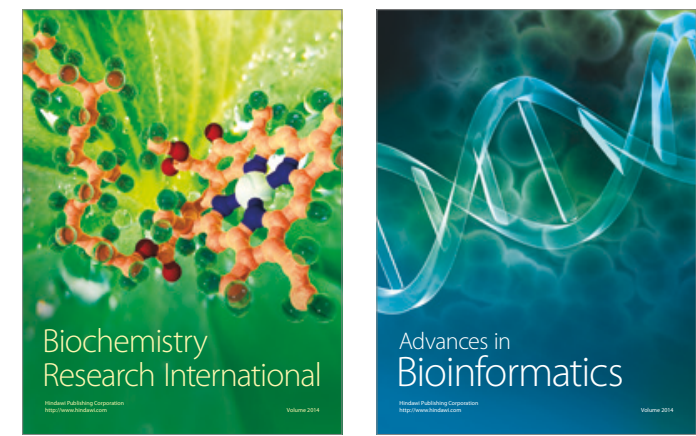

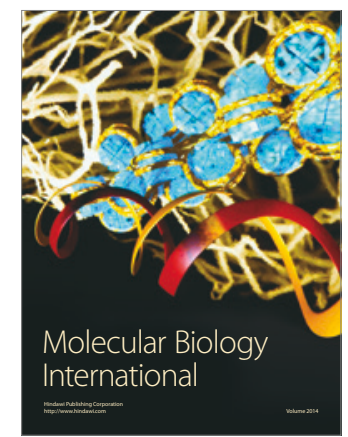

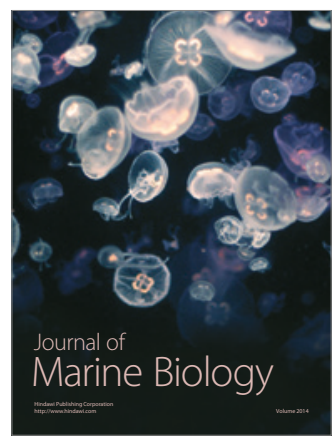

